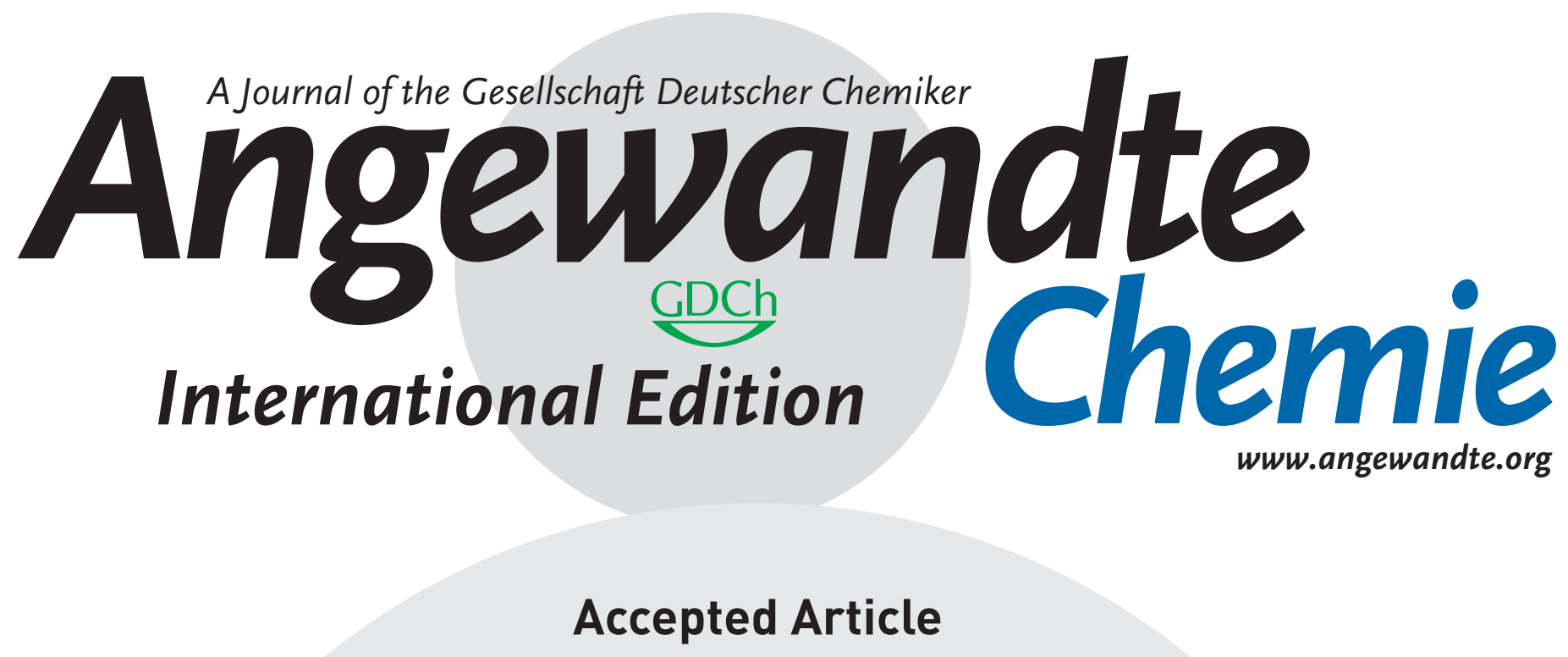

Title: Enhanced Reactivity of Accessible Protons in Sodalite Cages of Faujasite Zeolite

Authors: Xinyu Li, He Han, Wenqian Xu, Son-jong Hwang, Peng Lu, Aditya Bhan, and Michael Tsapatsis

This manuscript has been accepted after peer review and appears as an Accepted Article online prior to editing, proofing, and formal publication of the final Version of Record (VoR). This work is currently citable by using the Digital Object Identifier (DOI) given below. The VoR will be published online in Early View as soon as possible and may be different to this Accepted Article as a result of editing. Readers should obtain the VoR from the journal website shown below when it is published to ensure accuracy of information. The authors are responsible for the content of this Accepted Article.

To be cited as: Angew. Chem. Int. Ed. 10.1002/anie.202111180

Link to VoR: https://doi.org/10.1002/anie.202111180 


\title{
Enhanced Reactivity of Accessible Protons in Sodalite Cages of Faujasite Zeolite
}

\author{
Xinyu Li, ${ }^{\left[{ }^{[a]}\right.} \mathrm{He} \mathrm{Han},{ }^{[\mathrm{a}]}{ }^{[\mathrm{b}]}$ Wenqian Xu, ${ }^{[\mathrm{c}]}$ Son-Jong Hwang, ${ }^{[\mathrm{d}]}$ Peng Lu, ${ }^{[\mathrm{e}]}$ Aditya Bhan, ${ }^{* a]}$ and Michael \\ Tsapatsis*[a][e][f]
}

[a] X. Li, Dr. H. Han, Prof. A. Bhan, Prof. M. Tsapatsis

Department of Chemical Engineering and Materials Science, University of Minnesota, 421 Washington Avenue SE, Minneapolis, Minnesota 55455, United States

E-mail: abhan@umn.edu; tsapatsis@ihu.edu

[b] Dr. H. Han

State Key Laboratory of Fine Chemicals, PSU-DUT Joint Center for Energy Research, School of Chemical Engineering, Dalian University of Technology, Dalian, 116024, Liaoning Province, China

[c] Dr. W. Xu

X-ray Science Division, Advanced Photon Source, Argonne National Laboratory, Lemont, Illinois 60439, United States

[d] Dr. S.J. Hwang

Division of Chemistry and Chemical Engineering, California Institute of Technology, Pasadena, California 91125, United States

[e] Dr. P. Lu, Prof. M. Tsapatsis

Department of Chemical and Biomolecular Engineering \& Institute for NanoBioTechnology, Johns Hopkins University, 3400 North Charles Street, Baltimore, Maryland 21218, United States

[f] Prof. M. Tsapatsis

Applied Physics Laboratory, Johns Hopkins University, 11100 Johns Hopkins Road, Laurel, Maryland 20723, United States

Supporting information for this article is given via a link at the end of the document.

\begin{abstract}
Faujasite (FAU) zeolites (with Si/Al ratio of ca. 1.7) undergo mild dealumination at moderate ion exchange conditions (0.01 to $0.6 \mathrm{M}$ of $\mathrm{NH}_{4} \mathrm{NO}_{3}$ solutions) resulting in protons circumscribed by sodalite cages becoming accessible for reaction without conspicuous changes to bulk crystallinity. The ratio of protons in sodalite cages $\left(\mathrm{H}_{\mathrm{SOD}}\right)$ to supercages $\left(\mathrm{H}_{\mathrm{SuP}}\right)$ can be systematically manipulated from 0 to ca. 1 by adjusting ammonium concentrations used in ion exchange. The fraction of accessible protons in the sodalite cages is assessed by virtue of infrared spectra for H-D exchange of deuterated propane based on the band area ratio of $\mathrm{OD}_{2620} / \mathrm{OD}_{2680}\left(\mathrm{OD}_{\text {sod }} / \mathrm{OD}_{\text {suP }}\right)$. Protons in sodalite cages $\left(\mathrm{H}_{\mathrm{SOD}}\right)$ show higher rate constants of propane dehydrogenation $\left(k_{D}\right)$ and cracking $\left(k_{\mathrm{C}}\right)$ than protons in supercages ( $H_{\text {sup }}$ ) plausibly due to confinement effects being more prominent in smaller voids. Rate constants of dehydrogenation and cracking including $k_{D} / k_{C}$ ratios are also augmented as the fraction of accessible protons in the sodalite cages is enhanced. These effects of accessibility and reactivity of protons in sodalite cages hitherto inconspicuous are revealed herein via methods that systematically increase accessibility of cations located in sodalite cages.
\end{abstract}

\section{Introduction}

Faujasite (FAU) zeolites contain a three-dimensional microporous framework composed of supercages and sodalite cages, with the latter being connected via hexagonal prisms (Scheme 1). ${ }^{[1]}$ The large pore size with a free diameter of $7.4 \AA$ for 12 -membered ring (12-MR) channels, which constitute the aforementioned supercage, are primarily why FAU zeolites are utilized as catalysts for fluid catalytic cracking (FCC) ${ }^{[2]}$ As-synthesized Na-form FAU (Na-FAU) zeolites need to be transformed to $\mathrm{H}$-form FAU ( $\mathrm{H}-\mathrm{FAU}$ ) zeolites via ion exchange on non-framework cation positions to enable acid catalysis. ${ }^{\left[{ }^{12]}\right]}$ Not infrequently, the high ammonium concentrations employed for ion exchange lead to partial framework collapse (e.g., $1 \mathrm{M}$ of aqueous $\mathrm{NH}_{4} \mathrm{NO}_{3}$ solution) ${ }^{[3]}$ or formation of intracrystalline mesopores (e.g., $3 \mathrm{M}$ of aqueous $\mathrm{NH}_{4} \mathrm{Cl}$ solution) ${ }^{[4]}$ by dissolution and removal of framework Al atoms. ${ }^{[2]}$ Correlating the structural changes of FAU frameworks caused by ion exchange and dealumination with its catalytic performance is stifled by the loss of crystallinity and emergence of amorphous phases, ${ }^{[4-5]}$ and this in turn has resulted in strenuous research effort being devoted to developing controllable dealumination and ion exchange protocols that preserve crystallinity. ${ }^{[1 \mathrm{a}, 2 \mathrm{~b}, 5 \mathrm{~b}, 6]}$

We show that FAU zeolites undergo mild dealumination at moderate ion exchange conditions (0.01 to $0.6 \mathrm{M}$ of $\mathrm{NH}_{4} \mathrm{NO}_{3}$ solutions), leading to controllable opening of sodalite cages and rendering the associated protons, ones with catalytic properties distinct from protons in supercages of FAU zeolites, accessible. A combination of techniques, viz., probe molecule infrared spectroscopy, synchrotron X-ray diffraction (XRD), Ar adsorption, ${ }^{27} \mathrm{Al}$ and ${ }^{29} \mathrm{Si}$ solid-state magic angle spinning (MAS) nuclear magnetic resonance (NMR), are used to demonstrate that a fraction of sodalite cages permit influx/efflux and reactions of propane. The intermediate molecular size of propane $(4.3 \AA)^{[7]}$ compared to the 6 MR window opening $(2.6 \AA)$ and cavity diameter $(6.6 \AA)$ of the sodalite cage (see Scheme 1) led us to select H-D exchange of deuterated propane as a probe reaction to study the accessibility and reactivity of protons in sodalite cages of FAU zeolites. Specifically, propane-accessible proton distributions in H-FAU zeolites herein are quantified via the infrared band area ratio of $\mathrm{OD}_{2620} / \mathrm{OD}_{2680}$ (i.e., $\mathrm{OD}_{\text {soo }} / \mathrm{OD}_{\text {sup). }}{ }^{[8]}$ Monomolecular $\mathrm{H}^{+}$-catalyzed probe reactions of propane facilitate comparison of dehydrogenation $\left(k_{D}\right)$ and cracking $\left(k_{C}\right)$ rate constants over the two kinds of protons ( $\mathrm{H}_{\text {sup }}$ and $\mathrm{H}_{\mathrm{SOD}}$ ). Both rates of propane dehydrogenation and propane cracking are prominently enhanced 

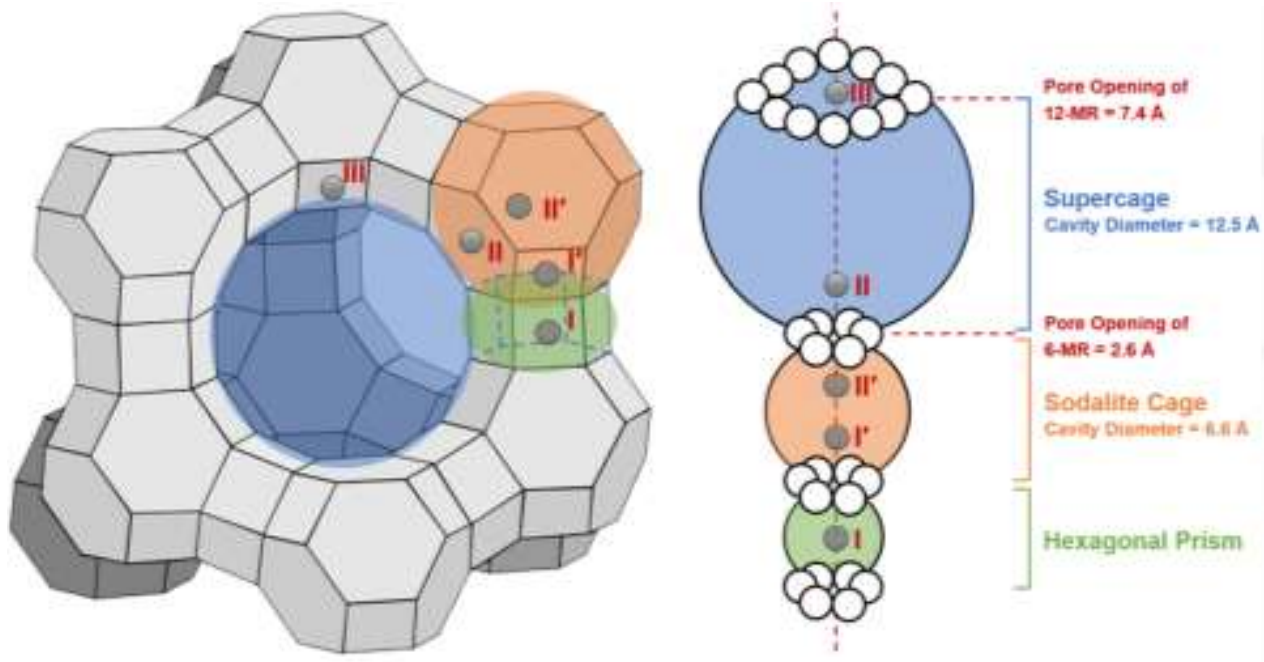

Scheme 1. Structure of faujasite framework with five types of non-framework cation positions (site I, I', II, II', and III). Adapted from ref [9]. The secondary building units of faujasite framework materials, supercage, sodalite cage, and hexagonal prism are marked as blue, orange, and green, respectively.

on $\mathrm{H}_{\text {SOD }}$ in reference to $\mathrm{H}_{\text {SuP }}$ plausibly due to enhanced confinement effects in smaller voids. ${ }^{[10]}$

\section{Results and Discussion}

\section{Characterization results for properties of H-FAU zeolites}

Different levels of ammonium concentrations (i.e., $0.01 \mathrm{M}, 0.05 \mathrm{M}$, $0.2 \mathrm{M}, 0.4 \mathrm{M}$, and $0.6 \mathrm{M}$ ) were selected to perform ion exchange. In all ion exchange experiments we used $0.25 \mathrm{~g}$ zeolite per $40 \mathrm{~mL}$ of ammonium solution. XRD patterns (Figure 1(a)) show that all $\mathrm{H}-\mathrm{FAU}$ zeolites preserve the FAU phase with high diffraction crystallinity upon ion exchange. SEM images (Figure S1) show that all H-FAU zeolites maintain the morphology and size of zeolite particles. Aradsorption isotherms (Figure 1(b)) show that the microporous volume of the FAU framework can be affected by the ammonium concentrations employed. An increase of overall pore volume is observed when the ammonium concentration is elevated to $0.2 \mathrm{M}$ and 0.4M (Figure 1(b), Figure S2, Table 1), and this trend does not continue at higher ammonium concentrations (H-FAU-0.6M). Limited by the small pore size of 6-MR with a free diameter of $2.6 \AA$ (Scheme 1), ${ }^{[1 \mathrm{a}]}$ intact sodalite cages are inaccessible for argon molecules with a molecular diameter of $3.4 \AA{ }^{.}{ }^{[11]}$ We hypothesize that the enhanced microporous volume results from: (1) an enhancement in size of pore openings and accessible pore volume due to the replacement of $\mathrm{Na}^{+}$with smaller $\mathrm{H}^{+}$ions, ${ }^{[12]}$ and/or (2) sodalite cages made accessible by partial removal of framework $\mathrm{Al}$ atoms. ${ }^{27} \mathrm{Al}$ solid-state MAS NMR spectra (Figure S3(a)) acquired subsequent to ion exchange with $\mathrm{NH}_{4} \mathrm{NO}_{3}$ reveal the formation of octahedral extra-framework Al (EFAI) on H-FAU zeolites, ${ }^{[1 a, 3]}$ which affirms the occurrence of mild dealumination. ${ }^{29} \mathrm{Si}$ solid-state MAS NMR spectra (Figure S3(b) and Table S1) were used to determine the distribution of $\mathrm{Q}^{4}(\mathrm{nAl}) \mathrm{Si}$ species on FAU zeolites. The existence of $\mathrm{Q}^{2} \mathrm{Si}$ species (a shoulder peak at $\left.\sim-88 \mathrm{ppm}\right)^{[13]}$ in these spectra
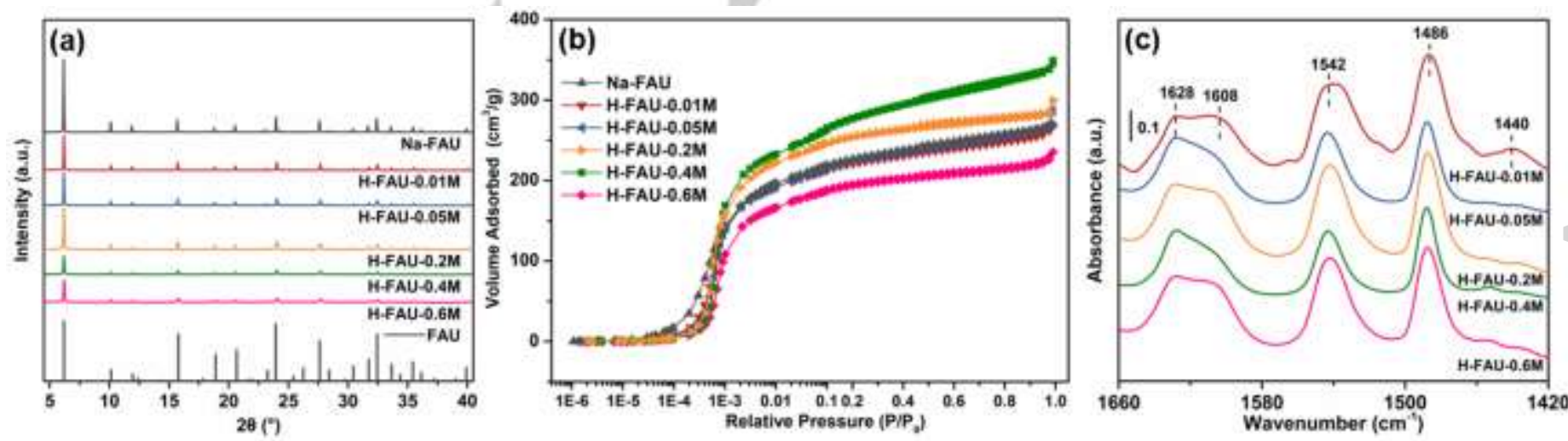

Figure 1. Characterization results of $\mathrm{Na}-\mathrm{FAU}$ and partially ion exchanged Na-FAU, denoted as $\mathrm{H}-\mathrm{FAU}-0.01 / 0.05 / 0.2 / 0.4 / 0.6 \mathrm{M}$ zeolites, corresponding to the $\mathrm{NH}_{4} \mathrm{NO}_{3}$ solutions used for ion exchange. (a) XRD patterns (plotted for the CuKa wavelength of $1.54059 \AA$ ) for $\mathrm{Na}$ - and $\mathrm{H}-\mathrm{FAU}$ zeolites converted from synchrotron XRD patterns (obtained using $0.45228 \AA$ ), and the standard pattern of FAU zeolite (PDF\#38-0240) is provided on the bottom. (b) Argon-adsorption isotherms for different $\mathrm{FAU}$ zeolites at $87 \mathrm{~K}$, in which $P / P_{0}$ from $10^{-6}$ to 0.1 is plotted logarithmically and $P / P_{0}$ from 0.1 to 1.0 is plotted linearly. (c) Infrared spectra for pyridine adsorption at $498 \mathrm{~K}$ over H-FAU zeolites. 
Table 1. Composition, $\mathrm{H}^{+}$density by pyridine titration, and porosity characteristics of FAU zeolites

\begin{tabular}{|c|c|c|c|c|c|c|c|c|c|}
\hline \multirow[b]{2}{*}{ Zeolite } & \multirow{2}{*}{$\begin{array}{l}\mathrm{Si} / \mathrm{Al} \\
\text { ratio }^{a}\end{array}$} & \multirow{2}{*}{$\begin{array}{l}\mathrm{Na} / \mathrm{Al} \\
\text { ratio }^{a}\end{array}$} & \multirow{2}{*}{$\begin{array}{l}(\mathrm{Si} / \mathrm{Al})_{\mathrm{F}} \\
\text { ratio }^{b}\end{array}$} & \multirow{2}{*}{$\begin{array}{l}\text { Chemical formula per zeolite unit cell } \\
\text { (including extraframework aluminum } \\
\left.\text { approximated as } \mathrm{Al}_{2} \mathrm{O}_{3}\right)^{c}\end{array}$} & \multicolumn{2}{|c|}{ Pyridine titrated $\mathrm{H}^{+}$} & \multirow{2}{*}{$\begin{array}{l}\text { Micropore } \\
\text { volume } \\
\left(\mathrm{cm}^{3} / \mathrm{g}\right)^{f}\end{array}$} & \multirow{2}{*}{$\begin{array}{c}\text { Mesopore } \\
\text { volume } \\
\left(\mathrm{cm}^{3} / \mathrm{g}\right)^{f}\end{array}$} & \multirow{2}{*}{$\begin{array}{c}\text { Pore } \\
\text { volume } \\
\left(\mathrm{cm}^{3} / \mathrm{g}\right)^{t}\end{array}$} \\
\hline & & & & & $\begin{array}{l}\text { Site density } \\
(\mu \mathrm{mol} / \mathrm{g})^{d}\end{array}$ & $\begin{array}{c}\text { Number per } \\
\text { unit celle }^{e}\end{array}$ & & & \\
\hline $\mathrm{Na}-\mathrm{FAU}$ & 1.7 & 0.99 & 1.62 & $\left(\mathrm{Na}_{71} \cdot 284 \mathrm{H}_{2} \mathrm{O}\right) \mathrm{Al}_{71} \mathrm{Si}_{121} \mathrm{O}_{384}$ & 0 & 0 & 0.332 & 0.057 & 0.389 \\
\hline H-FAU-0.01M & 1.7 & 0.64 & 1.88 & $\left(\mathrm{Al}_{2} \mathrm{O}_{3}\right)_{3.5}\left(\mathrm{Na}_{47} \cdot 189 \mathrm{H}_{2} \mathrm{O}\right) \mathrm{H}_{19.5} \mathrm{Al}_{67} \mathrm{Si}_{125} \mathrm{O}_{384}$ & 316 & 5.2 & 0.312 & 0.055 & 0.367 \\
\hline H-FAU-0.05M & 1.7 & 0.49 & 1.98 & $\left(\mathrm{Al}_{2} \mathrm{O}_{3}\right)_{5.3}\left(\mathrm{Na}_{37} \cdot 147 \mathrm{H}_{2} \mathrm{O}\right) \mathrm{H}_{27.7} \mathrm{Al}_{64} \mathrm{Si}_{128} \mathrm{O}_{384}$ & 226 & 3.5 & 0.308 & 0.063 & 0.371 \\
\hline H-FAU-0.2M & 1.7 & 0.36 & 2.00 & $\left(\mathrm{Al}_{2} \mathrm{O}_{3}\right)_{5.6}\left(\mathrm{Na}_{27} \cdot 108 \mathrm{H}_{2} \mathrm{O}\right) \mathrm{H}_{36.9} \mathrm{Al}_{64} \mathrm{Si}_{128} \mathrm{O}_{384}$ & 301 & 4.4 & 0.357 & 0.038 & 0.395 \\
\hline H-FAU-0.4M & 1.7 & 0.34 & 1.97 & $\left(\mathrm{Al}_{2} \mathrm{O}_{3}\right)_{5.1}\left(\mathrm{Na}_{25} \cdot 102 \mathrm{H}_{2} \mathrm{O}\right) \mathrm{H}_{39.2} \mathrm{Al}_{65} \mathrm{Si}_{127} \mathrm{O}_{384}$ & 271 & 3.9 & 0.364 & 0.097 & 0.461 \\
\hline H-FAU-0.6M & 1.7 & 0.34 & 1.99 & $\left(\mathrm{Al}_{2} \mathrm{O}_{3}\right)_{5.5}\left(\mathrm{Na}_{26} \cdot 102 \mathrm{H}_{2} \mathrm{O}\right) \mathrm{H}_{38.7} \mathrm{Al}_{64} \mathrm{Si}_{128} \mathrm{O}_{384}$ & 274 & 4.0 & 0.261 & 0.047 & 0.308 \\
\hline
\end{tabular}

${ }^{a}$ From ICP-OES analysis.

${ }^{b}$ Framework Si/Al ratios are determined from ${ }^{29} \mathrm{Si}$ MAS NMR data in accordance with "Loewenstein's rule" (equation 1). ${ }^{[14]}$

${ }^{c}$ Calculated via a combination of bulk Si/Al ratio (column 2), Na/Al ratio (column 3), and framework Si/Al ratio (column 4), considering that the total number of $\mathrm{T}$ atoms per unit cell is 192 and each $\mathrm{Na}^{+}$cation is coordinated with four water molecules. ${ }^{[15]}$ Extraframework aluminum content is approximated as $\mathrm{Al}_{2} \mathrm{O}_{3}$ and provided along with the zeolite unit cell formula. All numbers that appear in chemical formulae are rounded to the nearest integer, except $\mathrm{H}$ and $\mathrm{Al}_{2} \mathrm{O}_{3}$ components.

${ }^{d}$ Obtained from infrared spectra of pyridine adsorption (Figure 1(c)).

${ }^{e}$ Calculated by multiplying pyridine titrated $\mathrm{H}^{+}$density (column 6) with molecular weight per unit cell using chemical formulae (column 5).

${ }^{t}$ Obtained from analysis of argon-adsorption isotherms at $87 \mathrm{~K}$ using a DFT model assuming spherical micropores and cylindrical mesopores. ${ }^{[1 a]}$

also suggests mild dealumination of the framework occurs upon ion exchange. The framework Si/Al ratio of zeolite materials was calculated from these data with consideration of "Loewenstein's rule"(equation 1) ${ }^{[14]}$ prohibiting Al-O-Al linkages in the zeolite framework. ${ }^{[16]}$

$$
\frac{\mathrm{Si}}{\mathrm{Al}}=\sum_{x=0}^{4} I_{\mathrm{Si}(\mathrm{OAl})_{x}} / 0.25 \sum_{x=0}^{4} x I_{\mathrm{Si}(\mathrm{OAl})_{x}}
$$

An enhancement of framework $\mathrm{Si} / \mathrm{Al}$ ratio on $\mathrm{H}-\mathrm{FAU}$ zeolites compared to the parent Na-FAU zeolite was observed (Table 1, column 4), reflecting the removal of framework $\mathrm{Al}$ atoms from $\mathrm{H}$ FAU zeolites. The increase in microporous volume accompanying the formation of octahedral EFAl species on H-FAU zeolites indicates that mild dealumination takes place at moderate ion exchange conditions, which we hypothesize as the cause of accessible sodalite cages. Next, we describe probe molecule infrared studies that support this hypothesis.

Infrared spectra of dehydrated materials (Figure S4) can be used to differentiate proton locations in zeolites. The $\mathrm{OH}$ band at $\sim 3640 \mathrm{~cm}^{-}$ 1 is ascribed to $\mathrm{OH}$ groups in supercages, while the $\mathrm{OH}$ band at $\sim 3550 \mathrm{~cm}^{-1}$ is ascribed to $\mathrm{OH}$ groups in sodalite cages. ${ }^{[1 \mathrm{a},}{ }^{17]}$ Subtraction infrared spectra before and after pyridine adsorption are shown in Figure S5. The negative band at $3550 \mathrm{~cm}^{-1}$ for H-FAU0.05/0.2/0.4/0.6M (Figure S5) reflects perturbation of $\mathrm{H}^{+}$sites in accessible sodalite cages by pyridine molecules (with a molecular diameter of $5.8 \AA)^{[18]}$. The absence of a negative band at $\sim 3550 \mathrm{~cm}$ 1 for the H-FAU-0.01M (despite the presence of this band in the spectra of the dehydrated H-FAU-0.01M shown in Figure S4 (a)) is attributed to the inaccessibility of its intact sodalite cages. Infrared spectra measured upon adsorption of pyridine (Figure 1(c), Figure S6(b)) show that a band at $1440 \mathrm{~cm}^{-1}$, ascribed to pyridine molecules adsorbed on Lewis acid sites (e.g. $\mathrm{Na}^{+}$or $\left.\mathrm{Al}^{3+}\right),{ }^{[19]}$ is only observed on Na-FAU and H-FAU-0.01M. The band at $\sim 1540 \mathrm{~cm}^{-1}$ is ascribed to the interaction of pyridine with protons, ${ }^{[1 \mathrm{a}]}$ and proton densities (Table 1, column 6) can be assessed from the measured band area using the Lambert-Beer law and an extinction coefficient of $1.08 \pm 0.06 \mathrm{~cm} / \mu \mathrm{mol}$ (Figure S7), which was calculated as described in the Section on Experimental Methods for Infrared Spectroscopy in the Supporting Information. ${ }^{[17,20]}$

\section{Analysis of proton distribution on H-FAU zeolites}

Non-framework cation positions on FAU zeolites can be divided into five types (site I, I', II, II', and III) based on their specific locations (Scheme 1). ${ }^{[21]}$ Site $I$ is located at the center of hexagonal prisms and is surrounded by six oxygen atoms from the two bases of prisms, cations on site I are inaccessible to guest molecules. ${ }^{[2]}$ For sites located within sodalite cages, site $\mathrm{I}^{\prime}$ is located on the external bases of prisms, and site II' is located in the middle of 6-MR. [21a, 21b] For sites located within supercages, site II is located in the middle of 6-MR, and site III is located on the two neighboring 4-MRs. [21a, 21b] Charge repulsion exists between adjacent sites I and I', as well as adjacent sites II and II'. ${ }^{[22]}$ Therefore, when cations fully occupy site II, site II' is unoccupied by cations. ${ }^{[21 a, 22]}$ Site III, which possesses the highest coordinative unsaturation due to the fewest number of proximal oxygen atoms on 4-MRs, is the least occupied as evidenced previously by Lamberti and coworkers. ${ }^{[22]}$

To describe the distribution of extra-framework cations (and protons), we first estimate cation distribution via a combination of elemental analysis (ICP-OES and ${ }^{29} \mathrm{Si}$ MAS NMR) with infrared spectroscopy, and then we apply Rietveld refinement of XRD patterns to affirm the estimated cation distribution. Temperaturedependent in-situ synchrotron XRD patterns (Figures S8-S9) show that intensities of diffraction peaks at low angles increase with the ramping temperature due to water removal, followed by stable diffraction intensities when water removal is complete. XRD patterns of Na-FAU and H-FAU-0.4M before and after dehydration (Figures S10-S11, S15-S16, Tables S2-S3, S7-S8) reflect that sites II' and III are occupied by $\mathrm{H}_{2} \mathrm{O}$ before dehydration, and $\mathrm{H}_{2} \mathrm{O}$ on these sites can be fully removed after dehydration. The absence of $\mathrm{Na}^{+}$on site 
Table 2. $\mathrm{H}^{+}$distribution on $\mathrm{H}-\mathrm{FAU}$ zeolites

\begin{tabular}{|c|c|c|c|c|c|c|c|c|c|}
\hline \multirow{2}{*}{ Zeolite } & \multirow{2}{*}{$\begin{array}{c}\mathrm{H}^{+} \text {number } \\
\text { per unit } \\
\text { cella }\end{array}$} & \multirow{2}{*}{$\begin{array}{l}\mathrm{H}_{\text {SOD }} / \mathrm{H}_{\text {SuP }} \\
\text { (infrared) }^{b}\end{array}$} & \multicolumn{2}{|c|}{$\mathrm{H}_{\mathrm{SOD}}$} & \multicolumn{2}{|c|}{$\mathrm{H}_{\text {suP }}$} & \multirow{2}{*}{$\begin{array}{l}\text { ODsod/ODsup } \\
\text { (infrared) }^{e}\end{array}$} & \multicolumn{2}{|c|}{$\mathrm{H}_{\mathrm{SOD}}$, accessible } \\
\hline & & & $\begin{array}{c}\text { Number per } \\
\text { unit cell }{ }^{c}\end{array}$ & $\begin{array}{l}\text { Site density } \\
(\mu \mathrm{mol} / \mathrm{g})^{d}\end{array}$ & $\begin{array}{c}\text { Number per } \\
\text { unit cellc }\end{array}$ & $\begin{array}{l}\text { Site density } \\
(\mu \mathrm{mol} / \mathrm{g})^{d}\end{array}$ & & $\begin{array}{c}\text { Number per } \\
\text { unit cell }^{f}\end{array}$ & $\begin{array}{l}\text { Site density } \\
(\mu \mathrm{mol} / \mathrm{g})^{d}\end{array}$ \\
\hline H-FAU-0.01M & 19.5 & 0.36 & 5.2 & 316 & 14.3 & 878 & 0 & 0 & 0 \\
\hline H-FAU-0.05M & 27.7 & 1.02 & 14.0 & 900 & 13.7 & 882 & 0.41 & 5.6 & 362 \\
\hline H-FAU-0.2M & 36.9 & 1.39 & 21.5 & 1465 & 15.4 & 1054 & 0.76 & 11.7 & 801 \\
\hline H-FAU-0.4M & 39.2 & 1.40 & 22.9 & 1583 & 16.3 & 1131 & 1.31 & 21.4 & 1481 \\
\hline H-FAU-0.6M & 38.7 & 1.07 & 20.0 & 1380 & 18.7 & 1290 & 1.06 & 19.8 & 1367 \\
\hline
\end{tabular}

${ }^{a}$ Determined from chemical formulae (Table 1, column 5 ) in accordance with results of ${ }^{29} \mathrm{Si}$ MAS NMR and ICP-OES analysis.

${ }^{b}$ Calculated from the equation of $\mathrm{H}_{\mathrm{SOD}} / \mathrm{H}_{\mathrm{SUP}}=\left(\mathrm{OH}_{3550} / \varepsilon_{3550}\right) /\left(\mathrm{OH}_{3640} / \varepsilon_{3640}\right)$, and the infrared spectra of dehydrated H-FAU zeolites shown in Figure S4. Here, $\varepsilon(\mathrm{OH})_{3640}=6.76 \mathrm{~cm} / \mu \mathrm{mol}$, and $\varepsilon(\mathrm{OH})_{3550}=5.39 \mathrm{~cm} / \mu \mathrm{mol} .^{[1 \mathrm{a}, 23]}$

${ }^{c}$ Calculated via combining the summation of $\mathrm{H}_{\text {SOD }}+\mathrm{H}_{\text {SUP }}$ (namely $\mathrm{H}^{+}$number, column 2) and the ratio of $\mathrm{H}_{\text {SoD }} / \mathrm{H}_{\text {SUP }}$ (column 3).

${ }^{d}$ Calculated by dividing specific $\mathrm{H}^{+}$number per unit cell by the molecular weight using chemical formulae (Table 1, column 5).

${ }^{e}$ Obtained from infrared spectra of H-D exchange with deuterated propane over H-FAU zeolites at $623 \mathrm{~K}$ (Figure 2$)$. OD $D_{\text {sod }} / \mathrm{OD}_{\text {sup }}$ ratio is calculated from the ratio of $\left(\mathrm{OD}_{2620} / \varepsilon_{2620}\right) /\left(\mathrm{OD}_{2680} / \varepsilon_{2680}\right)$, in which the band area ratio of $\mathrm{OD}_{2620} / \mathrm{OD}_{2680}$ is obtained from Figure 2(g). We assume that the extinction coefficient ratio between protons with two kinds of locations (SOD and SUP) remains the same for both OD and OH groups, which means that $\varepsilon_{2620} / \varepsilon_{2680}=\varepsilon_{3550} / \varepsilon_{3640}=0.80$.

${ }^{f}$ Calculated from the equation of $\mathrm{H}_{\text {SOD, accessible }}=\mathrm{H}_{\text {SUP }} \times\left(\mathrm{OD}_{\text {SOD }} / \mathrm{OD}_{\text {SUP }}\right)$. We assume that $\mathrm{OD}_{\text {SOD }} / \mathrm{OD}_{\text {sup }}$ ratio represents the ratio of $\mathrm{H}_{\text {SOD, accessible }} / \mathrm{H}_{\text {SUP }}$, with the premise that supercages are accessible for $C_{3} D_{8}$ molecules.

III is consistent with its low occupancy on high-silica FAU zeolites. ${ }^{[12]}$ As the $\mathrm{NH}_{4} \mathrm{NO}_{3}$ concentration increases, the number of $\mathrm{H}^{+}$per unit cell increases (Table 2, column 2). We consider the missing $\mathrm{Na}^{+}$cations to be replaced by protons. As stated above, infrared spectra of dehydrated zeolites (Figure S4) can be used to differentiate protons within sodalite cages $\left(\sim 3550 \mathrm{~cm}^{-1}\right)$ and supercages $\left(\sim 3640 \mathrm{~cm}^{-1}\right)$. $\left.{ }^{[10 a}, 10 \mathrm{~b}\right]$ Extinction coefficients $(\varepsilon)$ reported by Thibault- Starzyk et al. ${ }^{[23]}$ on FAU zeolites were used to calculate the ratio of protons circumscribed by sodalite cages $\left(\mathrm{H}_{\mathrm{SOD}}\right)$ and supercages $\left(\mathrm{H}_{\text {SUP }}\right)$ via the ratio of $\left(\mathrm{OH}_{3550} / \varepsilon_{3550}\right) /\left(\mathrm{OH}_{3640} / \varepsilon_{3640}\right)($ Table 2 , column 3). The $\mathrm{H}_{\text {Sod }} / \mathrm{H}_{\text {sup }}$ ratio can be combined with the total $\mathrm{H}^{+}$ number per unit cell (Table 2, column 2) to calculate $\mathrm{H}_{\text {sod }}$ and $\mathrm{H}_{\text {sup }}$ occupancies (Table 2, columns 4 and 6), which can be applied for the subsequent XRD refinement analysis. $\mathrm{H}_{\text {SOD }}$ and $\mathrm{H}_{\text {suP }}$ in Table 2 are higher than the pyridine titrated $\mathrm{H}^{+}$number per unit cell (Table 1 , column 7). We postulate this is because interactions between adsorbed pyridine species located within the same supercage, ${ }^{[24]}$ disallows all $\mathrm{H}^{+}$sites to be titrated by pyridine simultaneously.

Assuming that the $\mathrm{Na}^{+}$fractional occupancy of site I (inaccessible) and site III (least occupied) remained invariant, ${ }^{31}$ we adjusted the occupancies of sites I' and II to reflect the changes in $\mathrm{Na}^{+}$in the sodalite cage and supercage, respectively. We then examined the above-determined distribution of non-framework cations for consistency with synchrotron XRD patterns via the Rietveld refinement analysis (Table $S 10$, which is tabulated based on Figures S10-S17 and Tables S2-S9), and two parameters ( $R_{\mathrm{wp}}$ and $\left.R_{\mathrm{p}}\right)^{[25]}$ are provided to evaluate the refinement performance and affirm that XRD refinement analysis supports the cation distribution estimated by elemental analysis and infrared spectroscopy. $\mathrm{H}_{\text {SOD }} / \mathrm{H}_{\text {SuP }}$ ratio on $\mathrm{H}-\mathrm{FAU}-0.01 \mathrm{M}$ reached 0.36 (Table 2), which means that ion exchange preferentially takes place within supercages at the mildest ion exchange conditions. $\mathrm{H}_{\text {SOD }} / \mathrm{H}_{\text {SuP }}$ ratios on $\mathrm{H}-\mathrm{FAU}$ zeolites treated with higher ammonium concentrations $(0.2 / 0.4 / 0.6 \mathrm{M})$ are ca. unity, implying that proton exchange at high ammonium concentrations no longer occurs preferentially within supercages.

\section{$H-D$ exchange of deuterated propane}

$\mathrm{H}-\mathrm{D}$ exchange of deuterated propane (Equation 2) was selected to probe the accessibility of sodalite cages of the FAU framework, due to its intermediate molecular diameter $(4.3 \AA)$ between the 6-MR window size $(2.6 \AA)$ and the cavity diameter $(6.6 \AA)$ of sodalite cages.

$$
\mathrm{C}_{3} \mathrm{D}_{8}+\mathrm{HY} \rightarrow \mathrm{C}_{3} \mathrm{D}_{7} \mathrm{H}+\mathrm{DY}
$$

After dosing a given pressure of $\mathrm{C}_{3} \mathrm{D}_{8}$ to the infrared cell operated in batch mode, appearance of the OD band was monitored (Figure 2). The OD band at $\sim 2680 \mathrm{~cm}^{-1}$ that appears upon H-D exchange could be correlated with the consumption of the $\mathrm{OH}$ band at $\sim 3640$ $\mathrm{cm}^{-1}$, and along the same lines the OD band at $\sim 2620 \mathrm{~cm}^{-1}$ could be correlated with the consumption of the $\mathrm{OH}$ band at $\sim 3550 \mathrm{~cm}^{-1}$ (Figures S18 S22). ${ }^{[8]}$ The H-FAU-0.01M zeolite contains protons within sodalite cages (with a $\mathrm{H}_{\text {SOD }} / \mathrm{H}_{\text {SUP }}$ ratio of 0.36 , Table 2 ), and the absence of an OD band at $\sim 2620 \mathrm{~cm}^{-1}$ (Figure 2(b)) is because this material contains intact sodalite cages that are inaccessible to propane molecules. When the ammonium concentration employed for ion exchange was increased from $0.01 \mathrm{M}$ to $0.4 \mathrm{M}$, the $\mathrm{OD}_{2620} / \mathrm{OD}_{2680}$ ratio increased monotonically (Figure $2(\mathrm{~g})$ ), which reflects an increase in accessibility of sodalite cages. The somewhat lower $\mathrm{OD}_{2620} / \mathrm{OD}_{2680}$ ratio for $\mathrm{H}-\mathrm{FAU}-0.6 \mathrm{M}$ compared to $\mathrm{H}-\mathrm{FAU}-0.4 \mathrm{M}$ (Figure 2(g)) is correlated with the decrease of microporous volume (Figure 1(b)) and could be attributed to partial structural collapse. As shown in Table 2, we calculate site densities in accessible sodalite cages $\left(\mathrm{H}_{\mathrm{SDO}}\right.$, accessible) via multiplying site densities in supercages $\left(\mathrm{H}_{\mathrm{SUP}}\right)$ with the band area ratio of $\mathrm{OD}_{\mathrm{SOD}} / \mathrm{OD}_{\text {Sup. }}$. We assume that $O D_{S O D} / O D_{\text {SuP }}$ ratio represents the ratio of $\mathrm{H}_{S O D}$, accessible $/ \mathrm{H}_{\text {SUP }}$, since both cages are accessible for $\mathrm{H}-\mathrm{D}$ exchange in reactions with $\mathrm{C}_{3} \mathrm{D}_{8}$. Propane, due to its smaller molecular size compared to pyridine, can titrate more $\mathrm{H}^{+}$sites within accessible 

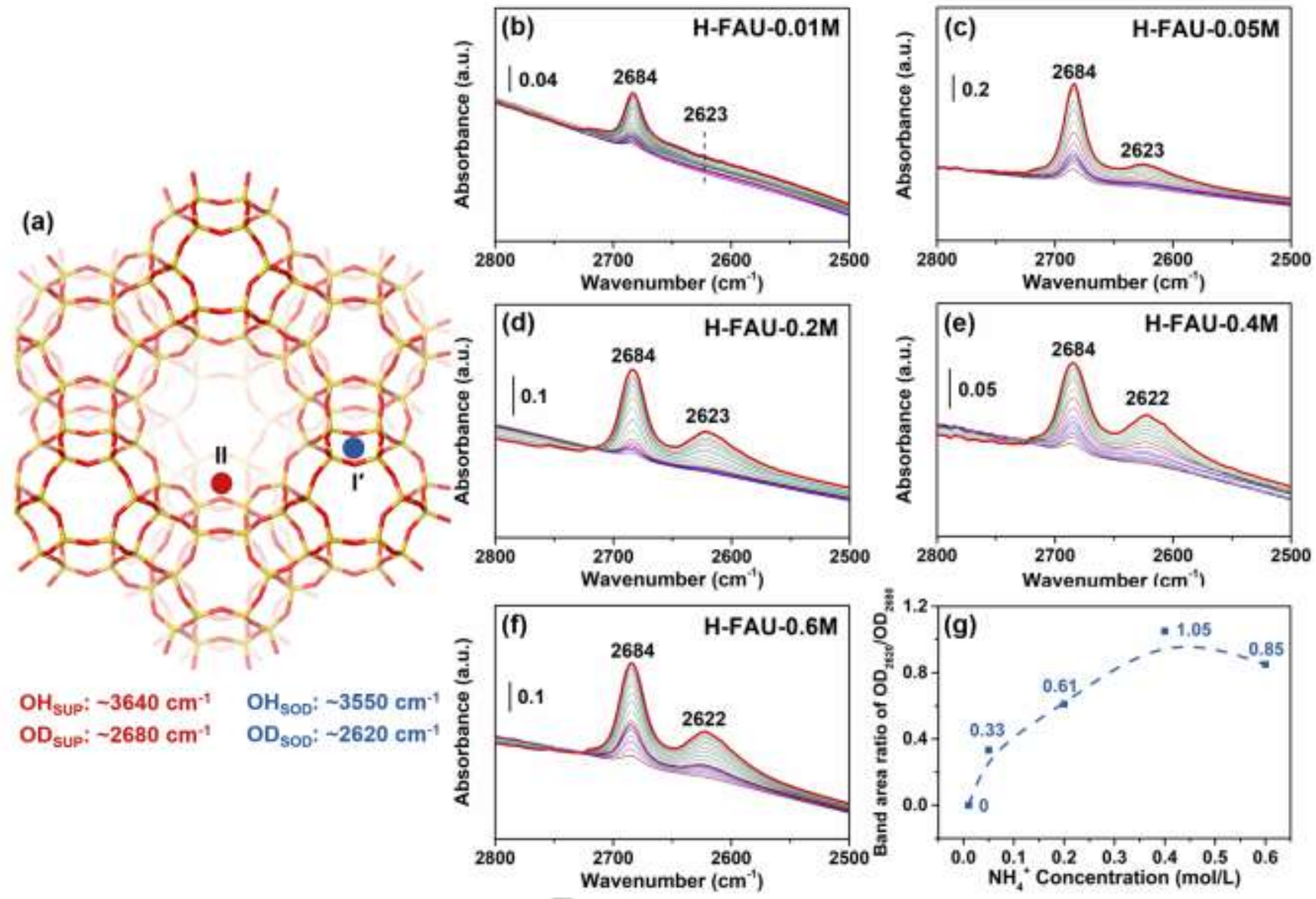

Figure 2. Infrared spectra for $\mathrm{H}-\mathrm{D}$ exchange with deuterated propane over H-FAU zeolites at $623 \mathrm{~K}$. (a) Scheme of two proton locations over H-FAU zeolites, (b) H-FAU-0.01M, (c) H-FAU-0.05M, (d) H-FAU-0.2M, (e) H-FAU-0.4M, (f) H-FAU-0.6M, and (g) band area ratio of OD ${ }_{2620} / \mathrm{OD}_{2680} \mathrm{Over} \mathrm{H}^{-}$ FAU zeolites pretreated with different ammonium concentrations. Dosing pressure of $\mathrm{C}_{3} \mathrm{D}_{8}$ equals $\sim 30$ Torr with operation as a batch reactor (with a total volume of ca. $240 \mathrm{~cm}^{3}$ ) and with spectra recorded after time intervals of $1 \mathrm{~h}$.

sodalite cages as shown in Table $\mathrm{S} 11$. Given that $\mathrm{C}_{3} \mathrm{D}_{8}$ shares the same molecular diameter as the probe molecule for monomolecular protolytic reactions $\left(\mathrm{C}_{3} \mathrm{H}_{8}\right)$, we deem that fractions of accessible $\mathrm{H}^{+}$ sites in sodalite cages assessed via H-D exchange of deuterated propane are more reliable than those assessed via pyridine adsorption. Site densities in accessible sodalite cages (Table 2, column 10) and supercages (Table 2, column 7) will be used to determine rate constants for protolytic alkane dehydrogenation and cracking in the next section.

\section{Comparison of rate constants for molecular protolytic reactions of propane}

Molecular dehydrogenation and cracking of propane (Equations 3 and 4) was employed as a diagnostic to test the relationship of proton reactivities with accessibility of sodalite cages on FAU zeolites.

$$
\begin{aligned}
& \mathrm{C}_{3} \mathrm{H}_{8} \stackrel{k_{\mathrm{D}}}{\longrightarrow} \mathrm{C}_{3} \mathrm{H}_{6}+\mathrm{H}_{2} \\
& \mathrm{C}_{3} \mathrm{H}_{8} \stackrel{k_{\mathrm{C}}}{\longrightarrow} \mathrm{C}_{2} \mathrm{H}_{4}+\mathrm{CH}_{4}
\end{aligned}
$$

A $7 \times$ difference in dehydrogenation rate constant on a per gram basis $\left(k_{D}\right.$, gcat) was observed between H-FAU-0.01M and H-FAU$0.4 \mathrm{M}$ from 818 to $893 \mathrm{~K}$ (Figure $3(\mathrm{a})$ ), and a $5 \times$ difference in cracking rate constant on a per gram basis $\left(k_{\mathrm{c}}\right.$, gcat $)$ was observed between $\mathrm{H}-\mathrm{FAU}-0.01 \mathrm{M}$ and H-FAU-0.6M (Figure 3(b)). Herein, we postulate that the enhanced accessibility of sodalite cages increases the fraction of $\mathrm{H}_{\mathrm{SOD}}$, accessible in the overall accessible proton densities, consequently leading to the increase of proton reactivities for molecular $\mathrm{H}^{+}$-catalyzed reactions of propane. H-FAU-0.01M only contains $\mathrm{H}_{\text {SuP }}$ (Table 2). Therefore, the $k_{\mathrm{C}}$ and $k_{\mathrm{D}}$ determined for this zeolite correspond to $k_{\mathrm{C} \text {,SuP }}$ and $k_{\mathrm{D}, \mathrm{SUP}}$, respectively. The specific contributions of $\mathrm{H}_{\mathrm{SOD}}$, accessible to measured rate constants ( $k_{\mathrm{C}, \mathrm{SOD}}$ and $\left.k_{\mathrm{D}, \mathrm{SOD}}\right)$ for the other H-FAU zeolites were determined from Equation 5.

$$
k_{\mathrm{SOD}}=\left(k_{\mathrm{gcat}}-k_{\mathrm{SUP}} \cdot \mathrm{H}_{\mathrm{SUP}}\right) / \mathrm{H}_{\mathrm{SOD} \text {, accessible }}
$$

The values of $\mathrm{H}_{\text {SUP }}$ and $\mathrm{H}_{\mathrm{SOD}}$, accessible used in Equation 5 are listed in Table 2. The procedure for their calculation has been described above and is summarized for convenience in Figure S23. Rate constants for $\mathrm{H}^{+}$in sodalite cages, $k_{\mathrm{C}, S O D}$ and $k_{\mathrm{D}, \mathrm{SOD}}$ are also shown 

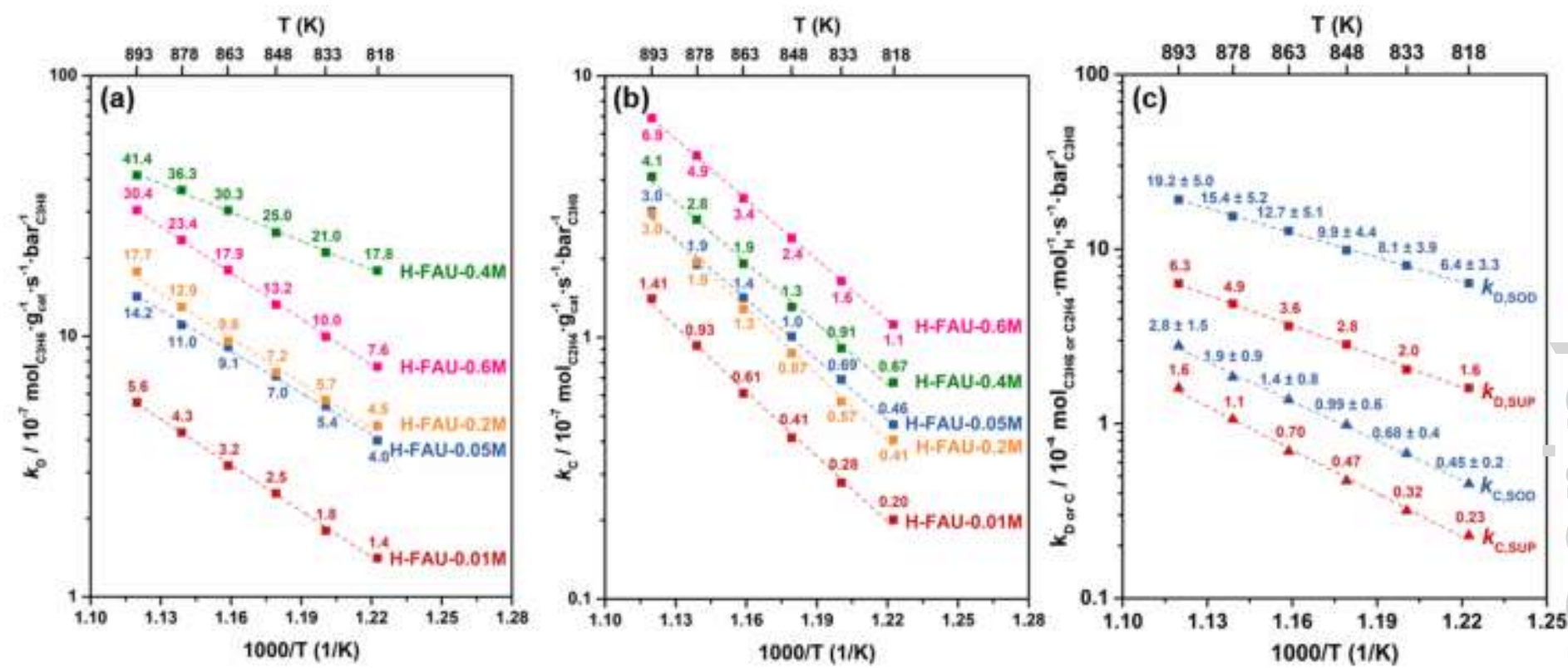

Figure 3. Analysis of rate constants for molecular cracking and dehydrogenation of propane over H-FAU zeolites. Temperature dependence of rate constants on a per gram basis for (a) dehydrogenation and (b) cracking over H-FAU zeolites. (c) Rate constants of $k_{\mathrm{D}, \mathrm{SOD}}, k_{\mathrm{C}, \mathrm{SOD}}, k_{\mathrm{D}, \mathrm{SUP}}$, and $k_{\mathrm{C}, \mathrm{SUP}}$ (on a per proton basis specific to sodalite cages and supercages) over $\mathrm{H}-\mathrm{FAU}$ zeolites. Reaction conditions: $\mathrm{C}_{3} \mathrm{H}_{8} / \mathrm{Ar} / \mathrm{He}=3 / 1.5 / 21$, with a total pressure of $110 \mathrm{kPa}$ and a total flow rate of $25.5 \mathrm{sccm}$, and space velocity $=3600 \mathrm{~cm}^{3} \mathrm{c}_{3 \mathrm{H}} \cdot \mathrm{gcat}^{-1} \cdot \mathrm{h}^{-1}$. Propane conversions are $<1 \%$. Standard deviations of $k_{\mathrm{D}, \mathrm{SOD}}$ and $k_{\mathrm{C}, \mathrm{SOD}}$ are provided in (c).

Table 3. Apparent enthalpic $\left(E_{\mathrm{a}}\right)$ and entropic $\left(\Delta S_{\mathrm{a}}\right)$ barriers for propane dehydrogenation and cracking over $\mathrm{H}_{\mathrm{SUP}}$ and $\mathrm{H}_{\mathrm{SOD}}$.

\begin{tabular}{lccccc}
\hline \multirow{2}{*}{ Proton } & \multicolumn{2}{c}{ Propane dehydrogenation } & & \multicolumn{2}{c}{ Propane cracking } \\
\cline { 2 - 3 } \cline { 5 - 6 } & $E_{\mathrm{a}}\left(\mathrm{kJ} \cdot \mathrm{mol}^{-1}\right)$ & $\Delta S_{\mathrm{a}}\left(\mathrm{J} \cdot \mathrm{mol}^{-1} \cdot \mathrm{K}^{-1}\right)$ & & $E_{\mathrm{a}}\left(\mathrm{kJ} \cdot \mathrm{mol}^{-1}\right)$ & $\Delta S_{\mathrm{a}}\left(\mathrm{J} \cdot \mathrm{mol}^{-1} \cdot \mathrm{K}^{-1}\right)$ \\
\hline HSUP & $48.9 \pm 1.0$ & $-210.0 \pm 1.2$ & & $68.9 \pm 2.2$ & $-192.6 \pm 2.5$ \\
HSOD & $39.0 \pm 0.6$ & $-217.0 \pm 0.6$ & & $62.5 \pm 1.4$ & $-197.7 \pm 1.6$ \\
\hline
\end{tabular}

in Figure S23, and their averages are given in Figure 3(c). Protons in accessible sodalite cages exhibit higher averaged rate constants (on a per proton basis) for both propane dehydrogenation (Equation 3 ) and propane cracking (Equation 4) reactions than protons in supercages. Iglesia and coworkers ${ }^{[10]}$ reported that for mordenite (MOR) zeolites, protons in 8-MR pockets exhibited higher rate constants than protons in 12-MR channels for monomolecular alkane cracking and dehydrogenation due to spatial constraints imposed by 8-MR pockets. They explained that a lower free energy for transition states within small 8-MR side pockets originated from entropic gains compensating for enthalpic penalties caused by spatial confinement of propane molecules within smaller 8-MR pocket voids. ${ }^{[10]}$ Herein, we attribute the enhanced rate constants of $\mathrm{H}_{\mathrm{SOD}}$, accessible to spatial confinement within smaller sodalite cages (with a cavity diameter of $6.6 \AA$ ) than in supercages (with a cavity diameter of $12.5 \AA$ ) of FAU zeolites. Differences in Brønsted acid site strength, as reflected by the deprotonation energies (DPE) of these aluminosilicates are not expected to be a major contributor [26] and we do not attempt to quantitate them here.

It is also observed that $k_{\mathrm{D}} / k_{\mathrm{C}}$ ratios on $\mathrm{H}_{\mathrm{SOD}}$, accessible $(\sim 7)$ are higher than those on $\mathrm{H}_{\text {sup }}(\sim 4)$, implying that monomolecular dehydrogenation is promoted to a greater extent than monomolecular cracking within smaller sodalite cages in line with results reported by Iglesia and coworkers ${ }^{[10 c, 10 d]}$ with the underlying premise that the variation in $k_{\mathrm{D}} / k_{\mathrm{C}}$ ratio reflects preferential stabilization of monomolecular propane dehydrogenation transition states due to partial confinement.

Apparent enthalpic $\left(E_{\mathrm{a}}\right)$ and entropic $\left(\Delta S_{\mathrm{a}}\right)$ barriers for propane dehydrogenation can be calculated from temperature dependence of dehydrogenation rate constants in Figure 3(c) via Equations 6 and 7:[27]

$$
\begin{gathered}
\ln (k)=\ln A-\frac{E_{\mathrm{a}}}{R T} \\
\Delta S_{\mathrm{a}}=R\left[\ln \left(\frac{A}{n_{\mathrm{b}}}\right)-\ln \left(\frac{k_{\mathrm{B}} T}{h}\right)\right]
\end{gathered}
$$

in which $n_{\mathrm{b}}, k_{\mathrm{B}}$, and $h$ represent the number of $\mathrm{C}-\mathrm{H}$ bonds ( 8 for

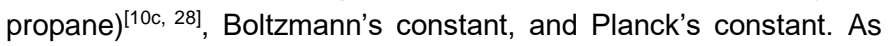
shown in Table 3, $E_{\mathrm{a}}$ and $\Delta S_{\mathrm{a}}$ for propane dehydrogenation over $\mathrm{H}_{\text {SUP }}$ are $48.9 \pm 1.0 \mathrm{~kJ} \cdot \mathrm{mol}^{-1}$ and $-210.0 \pm 1.2 \mathrm{~J} \cdot \mathrm{mol}^{-1} \cdot \mathrm{K}^{-1}$ respectively, while counterparts over $\mathrm{H}_{\mathrm{SOD}}$ are $39.0 \pm 0.6 \mathrm{~kJ} \cdot \mathrm{mol}^{-1}$ and $-217.0 \pm 0.6 \mathrm{~J} \cdot \mathrm{mol}^{-1} \cdot \mathrm{K}^{-1}$ respectively. From Figure $3(\mathrm{a})$, it is evident that the activation energy for dehydrogenation is lower in $\mathrm{H}$ - 
FAU-0.4M than that of the other tested catalysts. This can be attributed to $\mathrm{H}_{S O D}$ having a lower $E_{\mathrm{a}}$ than $\mathrm{H}_{\text {SUP }}$ for propane dehydrogenation, and $\mathrm{H}-\mathrm{FAU}-0.4 \mathrm{M}$ having the highest faction of accessible $\mathrm{H}_{\text {SOD }}\left(\mathrm{H}_{\mathrm{SOD}}\right.$, accessible $\left./ \mathrm{H}^{+}\right)$, as can be calculated from Table $2\left(\mathrm{H}_{\mathrm{SOD}}\right.$, accessible in column 9 , and $\mathrm{H}^{+}$in column 2$)$.

The measured apparent enthalpic (or entropic) barriers reflect the enthalpy (or entropy) difference between the dehydrogenation transition state (TS) in the intrazeolitic phase, and gas-phase propane and bare $\mathrm{H}^{+}$(Equations 8 and 9). Apparent enthalpic barriers for protolytic reactions are lower while the corresponding entropic barriers are higher in the sodalite cages in reference to $\mathrm{H}^{+}$ sites in supercages (Table 3). These enthalpic-entropic tradeoffs are characteristic of $\mathrm{H}^{+}$sites circumscribed in small pore cages and windows of zeolitic solids and have been reported previously for $\mathrm{H}$ MOR materials. ${ }^{[10 e, 27,29]}$ The lower $E_{\mathrm{a}}$ and $\Delta S_{\mathrm{a}}$ values for propane dehydrogenation relative to protolytic cracking reflect preferential stabilization of monomolecular propane dehydrogenation transition states due to partial confinement, ${ }^{[10 e, 27]}$ which is consistent with the higher $k_{\mathrm{D}} / k_{\mathrm{C}}$ ratios on $\mathrm{H}_{\mathrm{SOD}}$, accessible than $\mathrm{H}_{\mathrm{SuP}}$ as discussed above.

$$
\begin{gathered}
E_{\mathrm{a}}=E_{\mathrm{TS}}-E_{\mathrm{C} 3 \mathrm{H} 8(\mathrm{~g})}-E_{\mathrm{H}+} \\
\Delta S_{\mathrm{a}}=\Delta S_{\mathrm{TS}}-\Delta S_{\mathrm{C} 3 \mathrm{H} 8(\mathrm{~g})}-\Delta S_{\mathrm{H}+}
\end{gathered}
$$

In summary, we illustrate ion exchange procedures that open 6membered ring zeolite apertures, which are normally inaccessible due to their small openings $(2.6 \AA)$. This is achieved without loss of bulk crystallinity or porosity. Specifically, for FAU-type $\mathrm{Y}$ zeolite materials, a formulation that is used industrially for fluid catalytic cracking and alkylation, mild/moderate ion exchange protocols confer accessible protons of higher reactivity and specificity within sodalite cages. This work indicates that moderate ion exchange can be used as a general strategy for exploring molecular sieving effects on adsorption and reaction proffered by small channels, windows, and pores in zeolites that were considered inaccessible or unstable under typical ion exchange conditions and, as such, broaden the tools available to tune activity and selectivity in zeolite catalysis.

\section{Conclusions}

FAU zeolites undergo mild dealumination at moderate ion exchange conditions (0.01-0.6 M of aqueous $\mathrm{NH}_{4} \mathrm{NO}_{3}$ solutions; $0.25 \mathrm{~g}$ zeolite per $40 \mathrm{~mL}$ solution), resulting in controlled/partial access to proton sites in sodalite cages, as inferred from the infrared $O D_{2620} / O D_{2680}$ band area ratios acquired by virtue of $\mathrm{H}-\mathrm{D}$ exchange with deuterated propane. We find that protons in accessible sodalite cages are more reactive than protons in supercages, and that enhanced proton reactivities (on a per gram basis) for partially-dealuminated FAU materials arises from the increasing fraction of $\mathrm{H}_{\mathrm{SOD}}$ in the overall accessible proton densities. We posit that the enhanced reactivity for $\mathrm{H}_{\text {SOD }}$ over $\mathrm{H}_{\text {SuP }}$ is due to spatial constrains in smaller voids. In addition, the enhanced accessibility of sodalite cages increases the selectivity of dehydrogenation to cracking ( $k_{\mathrm{D}} / k_{\mathrm{C}}$ ratio) during molecular cracking of propane, implying that confinement within smaller sodalite cages preferentially stabilizes transition states for dehydrogenation.

\section{Associated Content}

\section{Supporting Information}

The Supporting Information is available on the website.

Experimental details, characterization data, including SEM images, infrared spectra, ${ }^{27} \mathrm{Al}$ and ${ }^{29} \mathrm{Si}$ solid-state MAS NMR, pore volume analysis, synchrotron XRD patterns.

\section{Conflict of Interest}

The authors declare no competing financial interest.

\section{Acknowledgements}

We acknowledge partial support from the Catalysis Center for Energy Innovation, an Energy Frontier Research Center funded by the U.S. Department of Energy, Office of Science, and Office of Basic Energy Sciences under Award No. DE-SC0001004. Partial support was also provided by the U.S. Department of Energy, Office of Basic Energy Sciences, Division of Chemical Sciences, Geosciences and Biosciences (Award DE-FG02-12ER16362). Partial support was also provided by the US Department of Energy, Office of Basic Energy Science, Catalysis Science Program (Award DE-SC00019028). Parts of this work were carried out in the Characterization Facility, University of Minnesota, which receives partial support from the NSF through the MRSEC and NNIN programs (DMR-1420013). Solid-state MAS NMR measurements were provided by the NMR facility at Caltech. The synchrotron XRD data were collected through the mail-in program at Beamline 17-BM of the Advanced Photon Source, a U.S. Department of Energy (DOE) Office of Science User Facility, operated for the DOE Office of Science by Argonne National Laboratory under Contract No. DEAC02-06CH11357.

Keywords: faujasite - accessible sodalite cage - ion exchange dealumination $\cdot$ confinement effect

[1] a) Z. Qin, K. A. Cychosz, G. Melinte, H. El Siblani, J.-P. Gilson, M. Thommes, C. Fernandez, S. Mintova, O. Ersen, V. Valtchev, J. Am. Chem. Soc. 2017, 139, 17273-17276; b) H. Awala, J. P. Gilson, R. Retoux, P. Boullay, J. M. Goupil, V. Valtchev, S. Mintova, Nat. Mater. 2015, 14, 447-451.

[2] a) E. T. C. Vogt, B. M. Weckhuysen, Chem. Soc. Rev. 2015, 44, 7342-7370; b) D. Verboekend, N. Nuttens, R. Locus, J. Van Aelst, P. Verolme, J. C. Groen, J. Perez-Ramirez, B. F. Sels, Chem. Soc. Rev. 2016, 45, 3331-3352.

[3] M. D. Oleksiak, K. Muraoka, M. F. Hsieh, M. T. Conato, A. Shimojima, T. Okubo, W. Chaikittisilp, J. D. Rimer, Angew. Chem. Int. Ed. 2017, 56, 13366-13371.

[4] D. Verboekend, T. C. Keller, S. Mitchell, J. Pérez-Ramírez, Adv. Funct. Mater. 2013, 23, 1923-1934.

[5] a) D. Verboekend, G. Vilé, J. Pérez-Ramírez, Adv. Funct. Mater. 2012, 22, 916-928; b) J. Van Aelst, D. Verboekend, A. Philippaerts, N. Nuttens, M. Kurttepeli, E. Gobechiya, M. Haouas, S. P. Sree, J. F. M. Denayer, J. A. Martens, C. E. A. Kirschhock, F. Taulelle, S. Bals, G. V. Baron, P. A. Jacobs, B. F. Sels, Adv. Funct. Mater. 2015, 25, 7130-7144; c) Z. Qin, B. Shen, X. Gao, F. Lin, B. Wang, C. Xu, J. Catal. 2011, 278, 266-275.

[6] a) T. C. Keller, S. Isabettini, D. Verboekend, E. G. Rodrigues, J. Pérez-Ramírez, Chem. Sci. 2014, 5, 677-684; b) C. Martinez, D. Verboekend, J. Perez-Ramirez, A. Corma, Catal. Sci. Technol. 
2013, 3, 972-981; c) D. Verboekend, J. Perez-Ramirez, Catal. Sci. Technol. 2011, 1, 879-890.

[7] H. T. Kwon, H.-K. Jeong, J. Am. Chem. Soc. 2013, 135, 1076310768.

[8] a) B. Schoofs, J. A. Martens, P. A. Jacobs, R. A. Schoonheydt, J. Catal. 1999, 183, 355-367; b) S. M. T. Almutairi, B. Mezari, G. A. Filonenko, P. C. M. M. Magusin, M. S. Rigutto, E. A. Pidko, E. J. M. Hensen, ChemCatChem 2013, 5, 452-466.

[9] C. Deng, J. Zhang, L. Dong, M. Huang, L. Bin, G. Jin, J. Gao, F. Zhang, M. Fan, L. Zhang, Y. Gong, Sci. Rep. 2016, 6, 23382.

[10] a) A. Bhan, A. D. Allian, G. J. Sunley, D. J. Law, E. Iglesia, J. Am. Chem. Soc. 2007, 129, 4919-4924; b) A. Bhan, E. Iglesia, Acc. Chem. Res. 2008, 41, 559-567; c) R. Gounder, E. Iglesia, J. Am. Chem. Soc. 2009, 131, 1958-1971; d) R. Gounder, E. Iglesia, Angew. Chem. Int. Ed. 2010, 49, 808-811; e) R. Gounder, E. Iglesia, Acc. Chem. Res. 2012, 45, 229-238.

[11] L. Pan, K. M. Adams, H. E. Hernandez, X. Wang, C. Zheng, Y. Hattori, K. Kaneko, J. Am. Chem. Soc. 2003, 125, 3062-3067.

[12] Y. Yang, N. Burke, J. Zhang, S. Huang, S. Lim, Y. Zhu, RSC Advances 2014, 4, 7279-7287.

[13] L. Qu, W. Zhang, P. J. Kooyman, R. Prins, J. Catal. 2003, 215, 713.

[14] C. A. Fyfe, Y. Feng, H. Grondey, G. T. Kokotailo, H. Gies, Chem. Rev. 1991, 91, 1525-1543.

[15] a) J. Rouquerol, P. Llewellyn, K. Sing, in Adsorption by Powders and Porous Solids (Second Edition) (Eds.: F. Rouquerol, J. Rouquerol, K. S. W. Sing, P. Llewellyn, G. Maurin), Academic Press, Oxford, 2014, pp. 467-527; b) M. C. Dalconi, G. Cruciani, A. Alberti, P. Ciambelli, M. T. Rapacciuolo, Micro. Meso. Mater. 2000, 39, 423-430.

[16] F. Dogan, K. D. Hammond, G. A. Tompsett, H. Huo, W. C. Conner, S. M. Auerbach, C. P. Grey, J. Am. Chem. Soc. 2009, 131, 1106211079.

[17] R. Gounder, A. J. Jones, R. T. Carr, E. Iglesia, J. Catal. 2012, 286, 214-223.

[18] E. Xing, Y. Shi, W. Xie, F. Zhang, X. Mu, X. Shu, Micro. Meso. Mater. 2016, 236, 54-62.

[19] I. Khalil, C. M. Celis-Cornejo, K. Thomas, P. Bazin, A. Travert, D. J. Pérez-Martínez, V. G. Baldovino-Medrano, J. F. Paul, F. Maugé, ChemCatChem 2020, 12, 1095-1108.

[20] B. M. Murphy, J. Wu, H. J. Cho, J. Soreo, C. Wang, L. Ma, B. Xu, ACS Catal. 2018, 1931-1942.

[21] a) S. Calero, D. Dubbeldam, R. Krishna, B. Smit, T. J. H. Vlugt, J. F. M. Denayer, J. A. Martens, T. L. M. Maesen, J. Am. Chem. Soc. 2004, 126, 11377-11386; b) S. Prodinger, A. Vjunov, J. Z. Hu, J. L. Fulton, D. M. Camaioni, M. A. Derewinski, J. A. Lercher, Chem. Mater. 2018, 30, 888-897; c) D. H. Olson, Zeolites 1995, 15, 439443.

[22] G. L. Marra, A. N. Fitch, A. Zecchina, G. Ricchiardi, M. Salvalaggio, S. Bordiga, C. Lamberti, J. Phys. Chem. B 1997, 101, 10653-10660.

[23] F. Thibault-Starzyk, B. Gil, S. Aiello, T. Chevreau, J.-P. Gilson, Micro. Meso. Mater. 2004, 67, 107-112.

[24] F. E. Celik, T.-J. Kim, A. T. Bell, J. Catal. 2010, 270, 185-195.

[25] G. Agostini, C. Lamberti, L. Palin, M. Milanesio, N. Danilina, B. Xu, M. Janousch, J. A. van Bokhoven, J. Am. Chem. Soc. 2010, 132, 667-678.

[26] A. J. Jones, E. Iglesia, ACS Catal. 2015, 5, 5741-5755.

[27] S. S. Arora, Z. Shi, A. Bhan, ACS Catal. 2019, 9, 6407-6414.

[28] R. Gounder, E. Iglesia, J. Catal. 2011, 277, 36-45.
[29] A. Bhan, R. Gounder, J. Macht, E. Iglesia, J. Catal. 2008, 253, 221224.

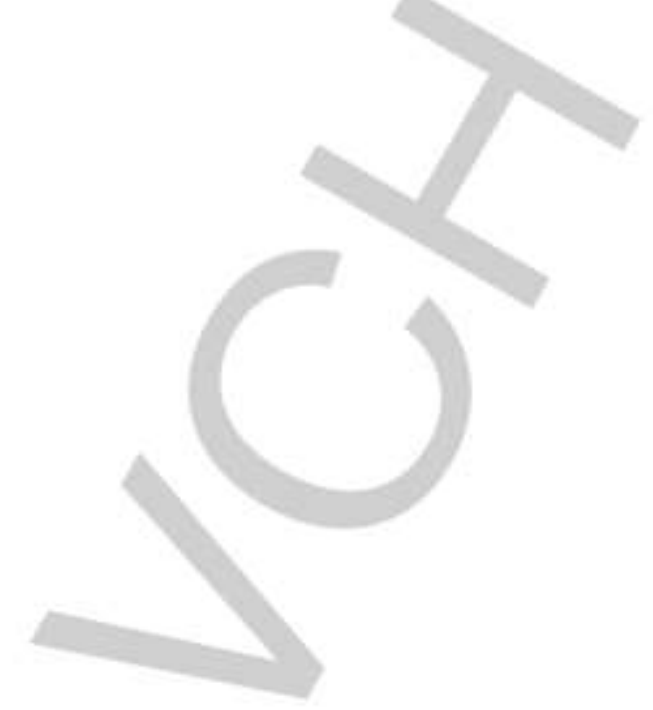




\section{Table of Contents}

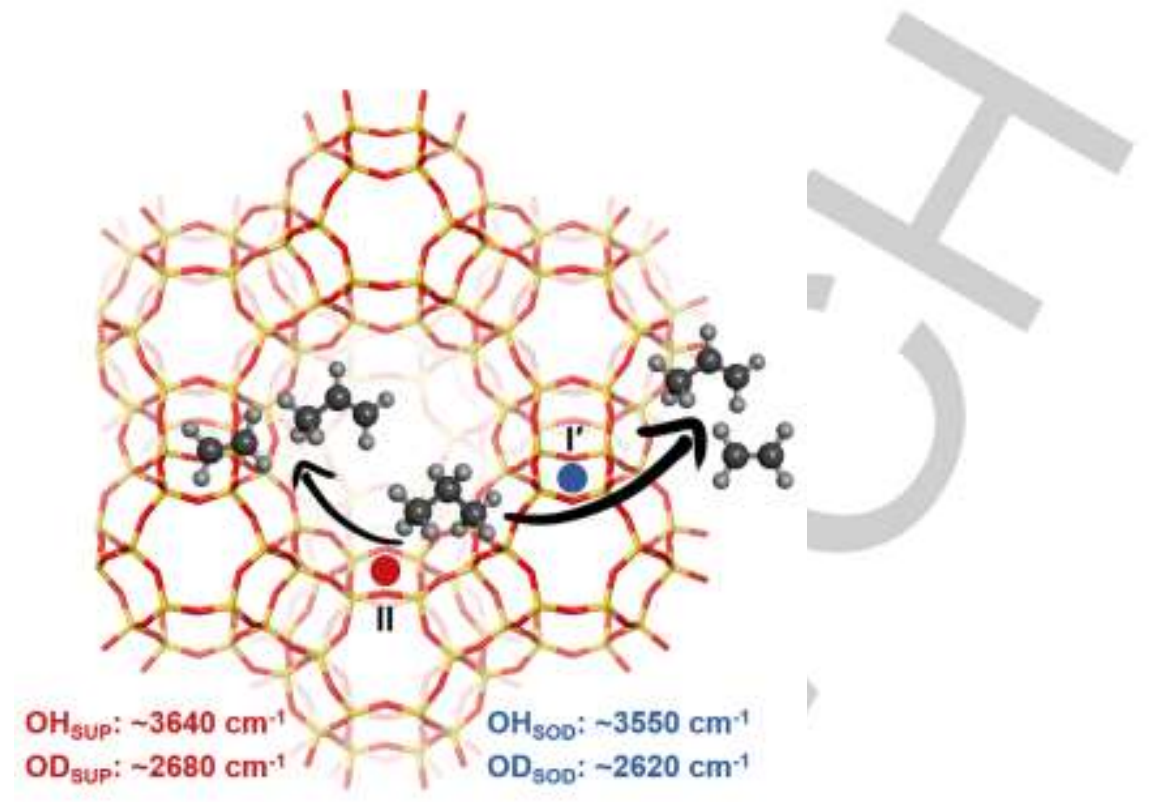

Faujasite (FAU) zeolites (with $\mathrm{Si} / \mathrm{Al}$ ratio of ca. 1.7) undergo mild dealumination at moderate ion exchange conditions (0.01 to $0.6 \mathrm{M}$ of $\mathrm{NH}_{4} \mathrm{NO}_{3}$ solutions) resulting in protons circumscribed by sodalite cages becoming accessible for reaction. The ratio of protons in sodalite cages $\left(\mathrm{H}_{\mathrm{SOD}}\right)$ to supercages $\left(\mathrm{H}_{\mathrm{SUP}}\right)$ can be systematically manipulated by adjusting ammonium concentrations used in ion exchange. The fraction of accessible protons in the sodalite cages is assessed by virtue of infrared spectra for $\mathrm{H}-\mathrm{D}$ exchange with deuterated propane. Protons in sodalite cages $\left(\mathrm{H}_{\mathrm{SOD}}\right)$ show higher rate constants of propane dehydrogenation $\left(k_{\mathrm{D}}\right)$ and cracking $\left(k_{\mathrm{C}}\right)$ than protons in supercages ( $\left.\mathrm{H}_{\text {SuP }}\right)$ plausibly due to confinement effects being more prominent in smaller voids. 